\title{
Unending Wars: Is Nationalism the Snag?
}

\section{COLLINS NKAPNWO FORMELLA ${ }^{1}$}

\begin{abstract}
Nationalism has been the major cause of wars since time immemorial and the most pronounced of it was World War I. Although the rhetoric of nationalism is seemingly less used after the major wars, because it adopted a new name, 'self-determination' - as enshrined in the UN Charter, Chapter I article 1 -, it remains in the background of many political discussions today and we continually see a global rise in collectivism, marked by religious fundamentalists of ethnic nationalist ideologies, which have resulted in nothing but fierce conflicts in almost every part of the world. Having noticed this increasing phenomenon, this paper tries to establish the relationship that exists between the world's agenda to globalise and national interests, which have left the world in a rather saddened situation of protracted wars between and within states, and its main thesis is that nationalism has played and continues to play a major role in the violent conflicts that sparkle around the world today, in the guise of ethno-religious conflicts.
\end{abstract}

Keywords: nationalism, globalisation, ethnicity, war, political instability, religion

\section{Introduction}

Mankind has behaved more barbaric than any other living thing on earth and one would wonder why we just cannot stop fighting each other. Our human self has been betrayed on several occasions and the fraternity that binds us together as human beings holds no meaning again. This political upheaval marks the growing divisiveness in a world where no one is listening to the other. Globalists would rather say the world is becoming more than ever united, especially with growing technology. The two great wars and recent ones have presented us with a rather different view of nationalism, which no longer points to the identification of people with a common destiny and history, nor the desire for nation states to be independent from others and to be driven towards a common end. The First World War would be remembered to have erupted due to the desire of Slavic people to establish a unified Greater Serbia. This Pan-Slavic nationalism led to the assassination of Archduke Franz

1 Collins Nkapnwo Formella, PhD candidate, University of Public Service, e-mail: formella2014@gmail.com 
Ferdinand in Sarajevo in June 1914, thus WWI broke out, leaving behind the events that happened in former Yugoslavia. Nationalism today presents a great challenge to the global agenda that the world has set out to achieve, depressing all hopes that Fukuyama had envisaged in his 1992 book, ${ }^{2}$ in which he hoped the world after the end of the Cold War would spiral into peace as liberal democratic ideals continue to spread, marking an end to violent conflicts that characterised the century.

This paper tries to establish the relationship that exists between the world's agenda to globalise and growing scenes of self-determination, which have left the world in rather a saddened situation of protracted wars between and within states, The aim of this paper is to investigate the connection amid the globalisation scheme and increasing instances of self-determination in the world, which on the other hand is the sparkle behind the so many protracted conflicts in all corners of the globe, a situation described by Mary Kaldor ${ }^{3}$ as 'new wars', wars of identity politics based on ethnic, religious or tribal affiliations, with the primary aim to gain control of the state by a particular group over the other either locally or internationally. The main thesis suggests that nationalism has played and continues to play a major role the violent conflicts that characterize our today's world. The focal point of this paper is to highlight the fact that nationalism as in the past, still contributes greatly to the violent conflicts we face today. We face so many challenges in these present times and these challenges show no trace of lessening its grip on us, yet nationalism has stood as a major drawback to mankind's unified action to such challenges. Recent debates on technological disruptions and climate change have proven this thesis even more fruitful. Growth in nationalistic feelings in a globalising world has seen common problems even more complicated to be solved in unity and nationalistic winged parties around the world have proven to be even more violently opposed to common and unified solutions to challenges such as artificial intelligence, bio-engineering and climate change.

\section{Nationalism and the nation-state}

National interests have always been behind every country's agenda despite involvements in international affairs, and even globally, nation-states often do disagree to which approaches are the best to respond to major issues such as climate change and terrorism. Virtues of egalitarianism, which are resourceful in the resolution of common problems that more often than not transcend borders and that necessitate common and united solutions, have been largely impeded, because nations of the

2 See F Fukuyama, The End of History and the Last Man (New York: Perennial, 1992). Responding to the collapse of the Berlin Wall and the subsequent breakdown of the Soviet Union, the book is still highly recognised for its efforts, but recent years have seen the erection of more walls and greater restrictions around the walls, moving away from the ideology wars of the past to more ancestral delineations.

3 M Kaldor, 'In Defence of New Wars', Stability: International Journal of Security and Development 2, no 1 (2013), 2. 
world remain divided along nationalistic lines, which have become more and more pronounced these days. Refugee crisis, climate change, and even disease pandemics which increasingly require a concerted effort of all nations of the world, have persisted because nations continue to pursue their narrow interest at the expense of collective efforts, which always yield better results for all. President Trump's policy of 'America First' has been the center of several disputes when settling issues that concern the globe. All this is rooted in the belief that what is in the best interest of my country should not necessarily be that which is best for yours, so national interests come first. This drive for nationalism has propelled every country's agenda on top of every other's, thus creating situations of conflict that have put globalisation on a sinking hole. Joseph E. Stiglitz in his writings talks of the 'debates on how to restructure the institutions running the world... thus globalisation a major concern being' which must be vigilantly controlled. ${ }^{4}$ To better understand nationalism, it will be wise to know what this rather controversial term means.

First, it is the immediate derivative of the term nation, which stands for the sentiments of attachment to each other shared by members of a nation possessing a feeling of pride belonging to that. Many reasons contribute to this feeling of nationalism, and throughout the eighteenth, the twentieth and the twentyfirst centuries, this desire of members of a community to govern themselves as a state within the boundaries of a particular territorial jurisdiction have driven all humankind's activities. This fusion gives birth to the 'nation state' and nationalism has been the driving force behind nation-states agendas. Care however must be given while trying to define nationalism especially when linking it to faithfulness to the state and not the nation, because a nation could be a tribal grouping, or other subnational groupings clinging on their identity. This is because nationalism may adopt several guises out of the original idea of the state itself. This point is important because there exist some groups of nations who are propagating their nationalism in the hopes of creating a homeland state or, on the other hand, pursuing to fashion a nation for a state that is not existing yet, for example, the 'Biafrans' in Nigeria, or the Palestinians, who have, however, been recognised by a few established nationstates, and also the 'Ambazonians' in Cameroon. Nationalism may not be a major variable in the realist paradigm, but it remains a powerful weapon in global power politics. Not focusing very much on the differences between these two theories, converging, however, the attributes of these two isms permits me to discuss these two concepts as if they were a single theory, though they are not. Nationalism has been known to be the everyday life tool and real-world phenomenon shaping global politics between nation-states, but the fact that calculated actions of states end up securing their national interests has plagued the world which, though seemingly globalising in respect to technology and other aspects, remains highly divided and in a state of chaos. García-García investigates the relationship between nationalism and

4 JE Stiglitz, Making Globalisation Work (New York - London: W.W. Norton \& Company, 2006), 3-4. 
mass psychological degradation and recounts that earlier studies and researchers had linked nationalism to 'the harmful effects of prejudice, mental narrowness, ignorance, the painful and deplorable effects of fanaticism, intolerance and a strong drive to war. ${ }^{5}$ Looking at nationalism from another perspective than the conventional political science explanations, García-García brings in the voices of researchers in medicine and psychology to expose the ills of nationalism in the post war era.

Nationalists have in recent years been gaining popularity around the world and it is no coincidence that it is happening at the same time when natural disasters ranging from wild fires and droughts, to flooding and wars have become so unprecedented. Responses to these phenomena have yielded rather unspeculated results, making nationalists leaders who are 'us' focused, while many wish to see leaders with the larger thought of the betterment of the globe; their actions have been rather conservative and protective, especially when they are members of the safer zones and very hostile towards the external world. These nationalistic tendencies have stood as a very strong blockade to the realisation of unified global actions towards the resolution of global problems, and at worst it is even giving rise to class-based societies.

\section{Globalisation, yet a dream}

The rhetoric of the 'new world order' that marked the end of the Cold War and opened the way to globalisation has come with a lot of confusion, raising several questions as to the true meaning of globalisation. One would even think it to be a myth at some time in life, based on the way the human race behaves, in this age of ever increasing interconnectedness, as clearly visible in the cluster of activities in economics, with the production chain internationalising, technology going across national boundaries, and a large inter-change of ideologies and cultures.

Emphasising the growing geographical extensions between activities people carry out between national boundaries, Holm delineates globalisation to be 'the strengthening of political, social, cultural and economic relations across national boundaries,' stressing the importance of conscious and increasing global connectedness. This view, on the other hand, can be examined in terms of self-interested goals of states, which have seen a less cooperative, less productive society, defined more in terms of selfsurvival, leading to uneven growth and globalisation in a world where a common law is drafted in the form of the universal declaration of human rights.

The benefits of globalisation in the world can never be undermined. It has come through with many consequences both positive and negative, yet it is still believed to be more needed by the world than isolation. Looking at the world today, one would say globalisation may have failed to achieve its desired goals, that is, free world, a 'global

5 J García-García, 'After the Great War: Nationalism, Degenerationism and Mass Psychology', Journal of Social and Political Psychology 3, no 1 (2015), 103.

6 HH Holm, 'Introduction: What has Changed?' in Whose World Order? Uneven Globalization and the End of the Cold War, ed. by HH Holm and G Sørensen (London: Routledge, 1995), 1-7. 
village.' Stiglitz ${ }^{7}$ blames it for poor management. As earlier advanced, power politics has been put in front of its goals, and Stiglitz further describes the situation that 'the rules of the governing has been largely altered by powerful and technologically advanced countries... driven by their national interests... and they denied creating faire rules, even just a set of rules that would promulgate well-being of those in the less developed world'. National interests have, however, diverted the true intentions of globalisation, which in essence entails the creation and consolidation of a global market-place instead of autonomous national economies.

\section{The Snag!}

With improvements in technology and communication, people have over the years migrated and settled in different parts of the world and formed families, thus creating a mixture of races, cultures, religions and ethnicities. The need for coexistence had brought people of varied origins to live together in various parts of the globe for centuries and even millennia through the establishment of a social contract, as Hobbes writes. ${ }^{9}$ He further adds in his understanding of human nature that the human race is at some point unavoidably, utterly narcissistic and often derails from the general good to pursue only that which they identify to be individually beneficial to them; so has been the nature of global politics, as leaders react perfunctorily, being drawn to that which they see their immediate interests and behave repugnant to all which is of no benefit to their desires, but which could be for others; this leads to the break-down of the social contract, according to which man in his rational being had chosen to submit to the authority of a sovereign so as to be able to live in a harmonious society. The increase in globalisation has led to a recent resurge of nationalistic feelings across the globe that has driven nationalism again as the major agenda for statesmen. Expectations have failed, promises broken, cooperation and the human ability to work with one another - though seemingly increasing - remain pulled-back by nationalistic desires and pride of men. Nationalistic feelings have led to the rise of left-wing and far-right political parties, increase in secessionist movements, and even led to increase in terrorist activities since the September 2011 attacks. One would ponder why all this is happening now! Donald Trump, while accepting his nomination as the Republican candidate, in his statement stressed his plan to 'put America First', not the world, proclaiming 'Americanism, not globalism as their credo.' ${ }^{10}$ Since his nomination and eventual election as president of the United States, Trump's policy of 'America First' has created mixed feelings and reactions in the world. Protectionism

7 Stiglitz, Making Globalisation, 4.

8 Ibid.

9 See T Hobbes, Leviathan. Longman Library of Primary Sources in Philosophy (New York: Routledge, 2016).

10 Donald Trump's nomination speech in Cleveland, Ohio, 21 July 2016. 
in pursuing American agenda has distorted and created several conflicts within and without America and the world at large and nationalism has seemingly become one of the main snags of our era, from Trump's pronouncement to uprisings in Catalan, Ireland and even leading to Britain voting to leave the European Union, and many others.

Very much akin to the nationalism constants are the myths of capitalism, which all base their foundations on stories; they have greatly influenced the way the human being behaves. Yuval Noah Harari in his 2014 book elaborates greatly on these myths surrounding the human reasoning: what nationalism is currently doing is just like what religion before the age of enlightenment and during the jihadist periods did to humankind, no good but the unnecessary waste of human lives, for a course of which no one has actually proven to have seen the end. Flag bearers of nationalism today are bent ready to edify anyone who appears promising enough to bring to light their beliefs and the supposed destinies which they hold, while scapegoating ${ }^{11}$ anyone who tries to defy their sense of superiority. According to Van Evera, the genesis of many civil wars, have been the result of 'impartial treatment especially of a minority, ethnic or tribal group by the central government, who after years of disgruntledness gradually nurture their nationalistic feelings and resolve to violence as the sole means of liberating themselves to accomplish their political ambitions.12 In the same vein, the desire of a particular group of people with nationalistic feelings for what they distinguish to be their ancestral base may tilt such a group towards adopting force as the sole means towards attaining their objectives, especially when they have judged that they are liable to enough backing from an exterior elite that is ready to sponsor their activities. These have been the case with so many post-war conflicts, especially in the developing nations of the world. A most recent example has been the conflict that broke out in the two Anglophone regions of Cameroon in 2016, ${ }^{13}$ which busted out after years of unanswered questions as to the true position of the Anglophone identity; it has been on a table of cards between the dominant Francophone government and the international community, notably the United Nations, which has ignored addressing the status of the two regions since the plebiscite that ceded the two regions as part of a federal Cameroon, and that was later manipulated to form a unitary state.

Nationalism is the direct offshoot of the concept of nation, which encompasses people with feelings of attachment to each other, with a common sense of pride, belief in a common destiny and desire to stand tall above all others. Since the Peace of Westphalia, nationalism took a different form, often manifesting itself as the urge of these peoples with a common identity as a nation to rule over and control a particular territory which they believe is theirs, and even to a certain extent to occupy more through expansion and conquest. The claim and conquest of the Israelites over

11 YN Harari, Sapiens: A Brief History of Humankind (Random House India, 2014).

12 S Van Evera, 'Hypotheses on nationalism and war', International Security 18, no 4 (1994), 8.

13 Cameroon's Anglophone Crisis at the Crossroads, International Crisis Group Report No. 250, 2017. 
the territory which they presently occupy just further emphasises the strength of nationalism and to which extent it may go to form a state of their own; this culminates in the formation of the concept of a 'nation-state' due to their believe in a common destiny within a particular geographic demarcation. This view of nationalism based on nation-states has been the source of several conflicts the world witnesses today, because today's states, being legally geographically bounded, have within themselves several groupings of people, who, though bounded under the same legal boundaries, are of different origins and as such see themselves as different nations, with different historical beliefs. Calling today's countries nation-states will thus be very much misleading, especially if well investigated. A good example to mention will be the Turkish minority in Western Thrace, Greece - as Evelin Verhás noted -, who are of Turkish origin and have constantly struggled for rights and recognition in Greece. ${ }^{14}$ The formation of some of today's nation-states especially African states, were the result of the decisions of their former colonial masters, who carved out their territories according to their desires; these have remained the boundaries of these states, which in themselves are made up of people from several nations. These countries have in most cases been at the mercy of civil wars due to political differences between the various nations. Nations, as is commonly known, are in the third world known as tribes, and tribalism and nepotism has thriven and gained grounds especially in the poor state from which they were granted independence. The situation in postcolonial sub-Saharan Africa, as remarked Franck, shows a trend where people with different histories, culture and language desire - for the sake of moving forward to nationalism - to create a nation within the territorial boundaries that define them as a state, where originally there is no nation-state..$^{15}$

Looking at Nationalism from this standpoint will present a rather passionate investment in binding together human beings with a common sense of purpose, contained by given territorial boundaries eparating them from others. The fact that nationalism is used in a globalising world to achieve some purposes which on the other hand hampers the interests of other peoples makes it dangerous, and this is a possible cause of some wars we have today. So it may turn to be a curse, especially when the end results are cross country wars due to propaganda of the superiority of some nations over others instead of viewing nationality as a shared identity within the same territory. Nationalism turned out to have rather confusing political consequences, because the more we turn our reflections towards one country, the more we ignore issues concerning the planet, as leaders of super powers have denied to become denizens of our planet to whom we all belong, but have pushed forward their respective country agendas ahead in all international organisations, choosing to walk out of anything that does not favour them. Trump's announcement to walk

14 E Verhás, 'The Turkish Minority in Western Thrace: The Long Struggle for Rights and Recognition', Report, Minority Rights Group Europe, 2019. 3-11.

15 TM Franck, 'Tribe, Nation, World: Self-Identification in the Evolving International System', Ethics $\mathcal{E}$ International Affairs 11 (1997), 164. 
America out of the Paris Peace Accord came as a result of his desires to maintain the American economy on top. ${ }^{16}$ This nationalistic pronouncement has spurred a lot of debates around the globe. The truth remains that nationalism is a fiction, because no country or people can prove that they all come from the same bloodline, instead, they are just an assembly of people from different parts of the world who come together and settle for their mutual benefits is some territorial delimitation.

Scholarly views on nationalism as a major trigger for global conflicts have not been unnoticeable. Political advances such as the American invasion of Iraq as a means of fostering US national interests subsequent to September 11, 2001 have been exemplified by many researchers such as $\mathrm{McCartney}^{17}$ or Warren, Cederman and Sornette; ${ }^{18}$ also, Walt ${ }^{19}$ proposed that 'nationalism weakens global cooperation', and according to Schrock-Jacobson, it 'escalates hostility between nation-states'. ${ }^{20}$ Wars of interest incited and sponsored by great powers due to their nationalistic interests have plagued the Middle East and other parts of the world into conflict and this have had severe consequences that stand as a backdrop to globalisation and its quest to unite the world. The last two decades have seen the movement of no less than 272 million $^{21}$ people, with an increase of 14 million people since 2017. At least 64 per cent of these international migrants tend to move to the most industrialised nations of the world, and these increases in migration have led to upsurges of right-wing movements in these countries due to the rise of nationalistic feelings there. These have not been well received by many groups, and this has brought severe consequences for many of these nations such as the increase in terrorist activities. The Charlie Hebdo attacks, the bombings in London and many others have all been linked to Islamic uprisings and the rapid encroachment of Islam into the European culture. The 'Islamification' of Europe has created a chain of conflicts and internally broken many countries by sparking off new nationalistic sentiments against all followers of Islam in Europe, who are usually commonly referred to as 'uncivilised' and an ideological enemy, as described by Marine Le Pen representing France's far right political wing, who even goes as far as comparing Islamic migrants moving to France to 'wolves in a henhouse. ${ }^{22}$ Islamic nations have viewed such allegations not just as mere campaign speeches, but as a direct attack of their values; these have led to tensions between these nations and extremist Muslims continue to use these exclusions as a basis to launch attacks on

16 See 'Our Disgraceful Exit From the Paris Accord,' Opinion by the Editorial Board, The New York Times, June 1, 2017.

17 P McCartney, 'American Nationalism and U.S. Foreign Policy from September 11 to the Iraq War', Political Science Quarterly 119, no 3 (2004), 400.

18 LE Cederman, TC Warren and D Sornette, 'Testing Clausewitz: Nationalism, Mass Mobilization, and the Severity of War', International Organization 65, no 4 (2011), 606.

19 SM Walt, 'Nationalism rules', Foreign Policy, July 15, 2011.

20 GU Schrock-Jacobson, Fighting and Dying for One's Country: Nationalism, International Conflict, and Globalization, PhD Dissertation (State College: Pennsylvania, 2010), 25-28.

21 World Migration Report 2020, IOM. 2.

22 C Farand, 'Marine Le Pen Launches Presidential Campaign hardline speech', The Independent, February 5, 2017. 
these nations. Today's wars have been known to spin mostly around communities and how they relate to each other, as explained by Lake and Rothschild; the emergence of a power vacuum can quickly start up a violent conflict among communities, due to 'fears of what the future may bring as a result of issues of credibility and security dilemma. ${ }^{23}$ Mansfield and Snyder, in theorising nationalism and war, advanced that nationalistic revolutions are likely to result in war. ${ }^{24}$ The more the number of individuals holding nationalistic affiliations in a country, having lost the feeling of belonging and seeking to be part of their own state, the more is the likelihood of war erupting in such countries, as they would always transmit these feelings down to their generations, and these people will build up a violent confrontation whenever they feel ready to challenge their oppressors. Africa's youngest country, South Sudan, gained its independence from the Republic of Sudan on July 9, 2011, as a result of such pattern of nationalism, which eventually led to violent confrontation, despite the independence from the Republic of Sudan; the country has barely known peace as it plunged into another civil war just two years after jubilating independence as a nation. This broke out as a result of the disgruntledness of Riek Machar (Vice President), his Nuer tribesmen and other ethnic groups over their allegedly marginalised position by Salva Kiir and his Dinka tribesmen. The Darfur region in Sudan since the mid-2000s has not known peace either, due to ethno-religious conflicts, which, like the others mentioned in this study, was the first genocide of the $21^{\text {st }}$ century. The Rohingya's in Myanmar saw the dark moon since 2015, and the Central African Republic since 2017 had its own turn on the blood bath list, with rising tensions between the Christians and the Muslims. Similar was the earlier case during the Croatian war of independence, which saw the independence of Croatia from the Socialist Republic of Yugoslavia on June 25, 1991, after years of violent confrontations.

In January 2015, a Washington Post article by Brian Catlos brought to light a different line of thinking regarding the often religiously inclined sectarian conflict in the Middle East. It takes a rather different line of reasoning in which nationalism predates even the coming of Christianity and Islam and modern Judaism in the region to expose the common cultures and practices amongst the people. He links this to the European idea of nationalism, which traces nations as with 'one language, one people, and one religion. ${ }^{25}$ This ties the explanations of the wars in this region to the same pattern that happened in Europe, where peoples with different ethnicity and religion were being targeted and eliminated. He concluded insisting that: 'The collapse of religious tolerance and plurality in today's Middle East is not, then, a manifestation of some particularly Islamic barbarism or evidence of a return to the Middle Ages.

23 DA Lake and D Rothschild, 'Containing fear: The Origins and Management of Ethnic Conflict,' International Security 21, no 2 (1996), 41-42.

24 E Mansfield and J Snyder, 'Democratization and the Danger of War', International Security 20, no 1 (1995), 19-20.

25 BA Catlos, 'Religious nationalism finds a footing in the Middle East', The Washington Post, January 2, 2015. 
Nor is it religious in motivation, although it may be in expression. It is a symptom of what we call modernization, and its political framework: nationalism. ${ }^{26} \mathrm{He}$ further predicts that the future may even experience worse than what we see today. Although we presume nationalism to be loosening its grip on the affairs of the world as a result of globalisation and improvement in technology, it is, however, returning and always will be part of the world in some way or the other. Now we see it playing a major role in ethno-religious conflicts.

It is impossible to separate or disconnect the linkages between war and genocide, which have been the child borne out of excessive stiff nationalism witnessed in many communities around the world, especially during inter-state wars. Jones even goes ahead to describe both as the 'Siamese twins of history. ${ }^{27}$ Extreme nationalism often leads to the outbreak of total war when the tutelage pressures to achieve cultural and ethnic homogenisation attain their uttermost level of forbearance.

Nationalism and populism which can be understood as the rebellion of ordinary citizens against the political elites, the culture and the business elite are sides of the same coin, and this comes as a result of the disintegration of the social contract that holds our societies together. The institutions of the state fail to deliver the desires of people, history and current events shows that the leaders are prone to always turn to populism and nationalism to defend themselves, and this is unhealthy to coexistence. The ideas of patriotism and nationalism that continue to gain grounds today in our societies are results of the economic models that we have, which, while restricting the growth and distribution of people, their free movements across geographic borders, is first and foremost bent on increasing the growth of capital, its distribution and also transfer, making the relations of globalisation almost entirely fiscal. This has left people practically abandoned and disconnected, in a world where the problems are transnational, requesting full international cooperation to deal with them. The moral purpose of nationalism is increasingly faded with increasing income inequality that the world is faced with. We need to understand that the essence of liberalism is to encourage and level up people in terms of income and resource distribution, but unfortunately this is not what is going on, as failure to deliver has fuelled up the populist impulse across the trans-Atlantic world. The end result of these have been nothing less but the elections of populist leaders in the United States, the United Kingdom, Italy, Poland, Hungary and have increasingly gained grounds in many other countries around the globe.

The rhetoric of nationalism as a surge of contemporary and past conflicts remains a debate widely followed and it becomes even more 'difficult to determine whether nationalism is actually the cause or just an accompanying factor into the world's unending wars' as Posen explains. ${ }^{28}$ The connectivity between these two variables

26 Ibid.

27 A Jones, Genocide: A Comprehensive Introduction (New York: Routledge, 2010), 48.

28 BR Posen, 'Nationalism, the mass army, and military power', International Security 18, no 2 (1993), 122. 
have, though, received very little attention, as even scholars often neglect nationalism as a war causing factor, says Van Evera. ${ }^{29}$ Global and national leaders have made the problem of nationalism more noticeable, the original belief of people being that they are under an exclusive or single gigantic identity; having exclusive loyalty to the leaders has been slowly wrecked because others want to breakdown this gigantic identity into several smaller groups because they do not see it as meeting their needs. The reality remains that nationalistic feelings have been hardly unnoticeable in any conflicts the world has ever known. The underlying ideal political philosophy around nationalism has changed, as it is fractured due to the fact that it neither empowers nor cares much about the ordinary person anymore; and diagnosing the recent surges of nationalistic feelings from this assertion cannot be misleading. The immediate human reaction has retrograded and despite the cooperation in the world, countries, nationals will always want to put themselves first due to patriotism.

\section{Conclusion}

This piece has provided from a variety of sources some evidence to identify nationalism's role in the study of International Relations and judged the activities of global international institutions. In doing so, it adds to the already available knowledge and contributes a little bit to understanding how fluctuations in nationalistic feelings across the globe has provoked violent conflicts sparking either from religious, race and even during sporting activities, as explored by Bertoli. ${ }^{30}$ Nationalism remains a vital tool for national, social and political development and cohesion, but common grounds have often been largely ignored while translating them to global politics, thus nationalism can be seen as both a curse and boon, depending on the situations to which they are applied, and it is neither a universal virtue nor some absolute wickedness. The outbreak of global pandemics such as the aged long Ebola disease and the more recent recurrent corona virus, which have in their respective times kept the world as a whole in total panic -because they have no respect for geographic or man-made boundaries, nor do they require any visas to get into any country, or choose whom to affect -, have simply proven that the real problem of the world is the idea of us versus them, in-built in unhealthy nationalism. Countries of the world under the guise of nationalism have portrayed the most barbaric behaviour in human history and the empathy we face during global pandemics is that the guns become silent, as have been the case in the protracted conflicts in Syria, Yemen and Libya, which for years drew the world's attention with the inability to arrive at a ceasefire by all parties involved. With the results of these calamities ranging from natural ones such climate change to violent conflicts, which have literally touched every part of the world, not really in essence affecting the spear-headers of nationalism, who in

29 Van Evera, 'Hypotheses', 5.

30 AD Bertoli, 'Nationalism and Conflict: Lessons from International Sports', International Studies Quarterly 61, no 4 (2017), 835-849. 
the more profound understanding are the upper classes of the society, the bourgeois, the rich, the world lacks yet in globally concerted efforts at curbing this devastation, because of course some groups of people still benefit from the activities causing the devastation and again these groups in the worst-case scenario can afford to at least protect themselves to some extent in an event of total disaster. Nationalism today equates ethno-religiosity and is a maggot that is eating deep into the already worsening wound of the ills of human civilisation.

Without equally denying the possibility of correlation of biological warfare associated with the outbreak of these global pandemics and wars - as multiple sources have claimed already, claiming them to be politically created diseases and wars to weaken economies and gain economic pre-eminence above others -, the reality of things on ground remains that their actions are all based around nationalism and geared at achieving the good of a particular group or country over the other. From all these, nationalism's role in contemporary and past wars cannot be ignored.

\section{References}

Bertoli, AD: 'Nationalism and Conflict: Lessons from International Sports'. International Studies Quarterly 61, no 4 (2017), 835-849. DOI: 10.1093/isq/sqx029

Catlos, BA: 'Religious nationalism finds a footing in the Middle East'. The Washington Post, January 2, 2015. Available: www.washingtonpost.com/gdpr-consent/?next_url=https\%3a\%2f\%2fwww. washingtonpost.com $\% 2$ fopinions $\% 2$ freligious-nationalism-finds-a-footing-in-the-middleeast\%2f2015\%2f01\%2f02\%2fb1fca096-91f2-11e4-a900-9960214d4cd7_story.html (20. 06. 2020.)

Cameroon's Anglophone Crisis at the Crossroads. International Crisis Group Report No. 250, 2017. Available: www.crisisgroup.org/africa/central-africa/cameroon/250-cameroons-anglophone- crisiscrossroads (20.06. 2020.)

Cederman, LE, TC Warren and D Sornette: 'Testing Clausewitz: Nationalism, Mass Mobilization, and the Severity of War'. International Organization 65, no 4 (2011), 605-638. DOI: 10.1017/ s0020818311000245

Farand, C: 'Marine Le Pen Launches Presidential Campaign hardline speech'. The Independent, February 5, 2017. Available: www.independent.co.uk/news/world/europe/marine-le-pen-frontnational-speech-campaign-launch-islamic-fundamentalism-french-elections-a7564051.html (02. 07. 2020.)

Franck, TM: 'Tribe, Nation, World: Self-Identification in the Evolving International System'. Ethics E International Affairs 11 (1997), 151-169. DOI: 10.1111/j.1747-7093.1997.tb00025.x

Fukuyama, F: The End of History and the Last Man. New York: Perennial, 1992.

García-García, J: 'After the Great War: Nationalism, Degenerationism and Mass Psychology' Journal of Social and Political Psychology 3, no 1 (2015), 103-123. DOI: 10.5964/jspp.v3i1.371

Harari, YN: Sapiens: A Brief History of Humankind. Random House India, 2014.

Hobbes, T: Leviathan. Longman Library of Primary Sources in Philosophy. New York: Routledge, 2016. DOI: $10.4324 / 9781315507613$

Holm, HH: 'Introduction: What has Changed?' in Whose World Order? Uneven Globalization and the End of the Cold War, ed. by HH Holm and G Sørensen. London: Routledge, 1995. 1-7. DOI: $10.4324 / 9780429267857-1$ 
Jones, A: Genocide: A Comprehensive Introduction. New York: Routledge, 2010. DOI: 10.4324/ 9780203846964

Kaldor, M: 'In Defence of New Wars'. Stability: International Journal of Security and Development 2, no 1 (2013). DOI: 10.5334/sta.at

Lake, DA and D Rothschild: 'Containing fear: The Origins and Management of Ethnic Conflict.' International Security 21, no 2 (1996), 41-75. DOI: 10.1162/isec.21.2.41

Mansfield, E and J Snyder: 'Democratization and the Danger of War.' International Security 20, no 1 (1995), 5-38. DOI: $10.2307 / 2539213$

McCartney, P: 'American Nationalism and U.S. Foreign Policy from September 11 to the Iraq War'. Political Science Quarterly 119, no 3 (2004), 399-423. DOI: 10.2307/20202389

'Our Disgraceful Exit From the Paris Accord. Opinion by the Editorial Board. The New York Times, June 1, 2017. Available: www.nytimes.com/2017/06/01/opinion/trump-paris-climate-changeagreement.html (20. 06. 2020.)

Posen, BR: 'Nationalism, the mass army, and military power'. International Security 18, no 2 (1993), 80-124. DOI: $10.2307 / 2539098$

Schrock-Jacobson, GU: Fighting and Dying for One's Country: Nationalism, International Conflict, and Globalization. PhD Dissertation. State College: Pennsylvania, 2010.

Stiglitz, JE: Making Globalisation Work. New York - London: W.W. Norton \& Company, 2006.

Van Evera, S: 'Hypotheses on nationalism and war'. International Security 18, no 4 (1994), 5-39. DOI: $10.2307 / 2539176$

Verhás, E: 'The Turkish Minority in Western Thrace: The Long Struggle for Rights and Recognition'. Report, Minority Rights Group Europe, 2019. Available: https://minorityrights.org/wp-content/ uploads/2019/10/MRG_Rep_WThrace_EN_Sept19.pdf (04. 01. 2021.)

Walt, SM: 'Nationalism rules'. Foreign Policy, July 15, 2011. Available: https://foreignpolicy. com/2011/07/15/nationalism-rules/ (12.06. 2020.)

World Migration Report 2020. IOM. Available: www.iom.int/wmr/ (20. 06. 2020.) 